\title{
Gracilimonas tropica gen. nov., sp. nov., isolated from a Synechococcus culture
}

Correspondence
Byung C. Cho
bccho@snu.ac.kr

\author{
Dong H. Choi, ${ }^{1}$ Gwang I. Zhang, ${ }^{2}$ Jae H. Noh, ${ }^{1}$ Woong-Seo Kim ${ }^{1}$ \\ and Byung C. $\mathrm{Cho}^{2}$
}

\author{
${ }^{1}$ Open and Tropical Research Division, Korea Ocean Research and Development Institute, Ansan \\ 426-744, Republic of Korea
${ }^{2}$ School of Earth and Environmental Sciences and Research Institute of Oceanography, Seoul National University, Shillim-dong, Kwanak-gu, Seoul 151-742, Republic of Korea

\begin{abstract}
An irregular, long, rod-shaped marine bacterium, designated CL-CB462 ${ }^{\top}$, was isolated from a Synechococcus culture, which was established from surface water from the tropical Pacific Ocean. The physiological and biochemical features, fatty acid profile and phylogenetic position based on 16S rRNA gene sequences were investigated for the novel strain. Phylogenetic analysis of the 16S rRNA gene sequence showed that the closest relatives of strain CL-CB462 ${ }^{\top}$ were Balneola vulgaris and Balneola alkaliphila. Strain $\mathrm{CL}-\mathrm{CB} 462^{\top}$ formed a robust clade with members of the genus Balneola in all phylogenetic trees constructed by three different methods. However, the 16S rRNA gene sequence similarity was very low (91.3-91.5\% similarity) and phenotypic and physiological features could clearly differentiate strain CL-CB462 ${ }^{\top}$ from the genus Balneola. Cells of the novel strain were non-motile and spore-forming. The strain was able to grow at $1-20 \%(\mathrm{w} / \mathrm{v})$ (optimum of 3-6\%) sea salt concentration, at temperatures of 20$40{ }^{\circ} \mathrm{C}$ and between $\mathrm{pH} 6$ and 10 . The fatty acids were dominated by $15: 0$ iso (41.2\%) and $17: 1 \omega 9 c$ iso (21.4\%). The DNA G + C content was 42.7 mol\%. Based on polyphasic evidence, strain CL-CB $462^{\top}$ was considered to represent a new genus. The name Gracilimonas tropica gen. nov., sp. nov. is proposed for the type strain of the type species $\left(C L-C B 462^{\top}=K C C M\right.$ $90063^{\top}=$ DSM $19535^{\top}$ ).
\end{abstract}

According to Garrity et al. (2004), the family Crenotrichaceae within the Bacteroidetes consisted of five genera with validly published names. However, Stoecker et al. (2006) have presented molecular evidence that the genus Crenothrix, the type genus of the family, belongs to the order Methylococcales of the class Gammaproteobacteria. Consequently, other genera originally assigned to the family Crenotrichaceae within the order Sphingobacteriales are currently considered Sphingobacteriales genera incertae sedis, including the genera Rhodothermus (Alfredsson et al., 1988) and Salinibacter (Antón et al., 2002). Among these genera, two species have been isolated from extreme environments: Rhodothermus marinus was isolated from submarine hot springs in Iceland (Alfredsson et al., 1988) and Salinibacter ruber was isolated from hypersaline crystallizer ponds in Spain (Antón et al., 2002).

Abbreviation: ASW, artificial seawater.

The GenBank accession number for the 16S rRNA gene sequence of strain CL-CB462 ${ }^{\top}$ is EF988655.

Phylogenetic trees constructed with maximum-likelihood and maximumparsimony methods and a comparison of fatty acid compositions for strain CL-CB462 ${ }^{\top}$ and related species are available with the online version of this paper.
Thus, they show thermophilic and extreme halophilic characteristics, respectively. Recently, the genus Balneola, was isolated from surface waters in the coastal Mediterranean Sea and it is not extremophilic (Urios et al., 2006, 2008). In this study, strain CL-CB462 ${ }^{\mathrm{T}}$, which is affiliated with Balneola species, was isolated from a Synechococcus culture that had been established from seawater from the tropical Pacific Ocean and a polyphasic taxonomic analysis of the strain was performed.

The Synechococcus culture was maintained by transferring small quantities of culture to $f / 2$ medium (Guillard \& Ryther, 1962) supplemented with ammonium chloride (final concentration $100 \mu \mathrm{mol} \mathrm{l}^{-1}$ ). The culture was incubated at $25{ }^{\circ} \mathrm{C}$ under a light-dark regime $(14: 10)$ at approximately $20 \mu \mathrm{E} \mathrm{m}^{-2} \mathrm{~s}^{-1}$. To isolate other bacteria that had been maintained in the Synechococcus culture, $30 \mu \mathrm{l}$ culture at the exponential growth phase was spread on a marine agar 2216 (MA, Difco) plate and incubated at $25{ }^{\circ} \mathrm{C}$ for 1 week. Strain CL-CB462 ${ }^{\mathrm{T}}$ was isolated and subsequently purified with four rounds of subculture on $\mathrm{MA}$ at $30^{\circ} \mathrm{C}$. The strain was maintained both on MA at $4{ }^{\circ} \mathrm{C}$ and in marine broth 2216 (MB, Difco) supplemented with $30 \%(\mathrm{v} / \mathrm{v})$ glycerol at $-80{ }^{\circ} \mathrm{C}$. 
For 16S rRNA gene amplification by PCR, DNA was extracted from a single colony by a boiling method (Englen \& Kelley, 2000). The crude extracts served as the DNA template for PCR reactions with Taq DNA polymerase (Bioneer) and primers 27F and 1492R (Lane, 1991). PCR products were purified using the AccuPrep PCR Purification kit (Bioneer). Sequencing of the amplified $16 \mathrm{~S}$ rRNA gene fragment was performed with an Applied Biosystems automatic sequencer (ABI 3730XL) at Solgent Co., Daejeon, Korea. The almost-complete 16S rRNA gene sequence of strain CL-CB462 ${ }^{\mathrm{T}}$ (1392 bp) was obtained and compared with $16 \mathrm{~S}$ rRNA gene sequences available in GenBank using BLASTN (Altschul et al., 1990). The sequence was aligned with those of type strains of genera that are phylogenetically related to strain CL-CB462 ${ }^{\mathrm{T}}$ using the ARB program (Ludwig et al., 2004, available at www.arbhome.de) and the Silva database release 94 (Pruesse et al., 2007, available at www.arb-silva.de). The alignment was checked manually using the ARB_EDIT sequence editor. Phylogenetic trees were obtained by neighbour-joining (Saitou \& Nei, 1987) and maximum-parsimony (Fitch, 1971) methods using the MEGA version 4 program (Tamura et al., 2007). An evolutionary distance matrix for the neighbour-joining method was generated according to the model of Jukes \& Cantor (1969). The robustness of the tree topologies was assessed by bootstrap analyses based on 1000 replications for neighbour-joining and maximumparsimony methods. In addition, a maximum-likelihood tree was constructed using PAUP ${ }^{\star}$ version 4.0 (Swofford, 1998). Likelihood parameters were estimated by using the hierarchical ratio tests in MODELTEST version 3.04 (Posada \& Crandall, 1998) and bootstrap analysis based on 100 replications was conducted.

Morphological and physiological analyses were also performed. Gram-staining was conducted as described by Smibert \& Krieg (1994). Cell morphology and motility were examined by phase-contrast microscopy and transmission electron microscopy (EX2; JEOL) with cells grown for 3 days at $35{ }^{\circ} \mathrm{C}$ in $\mathrm{MB}$ and on MA. Anaerobic growth was checked on MA using the GasPak anaerobic system (BBL). Acid production from D-glucose was also tested on ZOF medium (Lemos et al., 1985) supplemented with $1 \%$ D-glucose. Endospores were detected by malachite green staining (Smibert \& Krieg, 1994). The presence of flexirubin-type pigments was investigated by using the bathochromatic shift test with a $20 \%(\mathrm{w} / \mathrm{v}) \mathrm{KOH}$ solution (Bernardet et al., 2002). Poly- $\beta$-hydroxybutyrate granules were examined by epifluorescence microscopy (BX60; Olympus) after Nile blue A staining (Ostle \& Holt, 1982).

The temperature range for growth was determined on the basis of colony formation on MA plates that were incubated at $5-45^{\circ} \mathrm{C}$. The $\mathrm{pH}$ range for growth in $\mathrm{MB}$ was determined by changes in $\mathrm{OD}_{600}$ with time for the $\mathrm{pH}$ range 5 to 11 by adjusting the final $\mathrm{pH}$ with $\mathrm{NaOH}$ and $\mathrm{HCl}$ solutions. Tolerance of strain CL-CB462 ${ }^{\mathrm{T}}$ to $\mathrm{NaCl}$ and sea salts was determined using synthetic ZoBell broth $\left(1^{-1}\right.$ distilled water: $5 \mathrm{~g}$ Bacto peptone, $1 \mathrm{~g}$ yeast extract, $0.1 \mathrm{~g}$ ferric citrate) with various concentrations $[0,1,2,3,4,5,6$, $7,8,9,10,15,18,20,23,25 \%(\mathrm{w} / \mathrm{v})]$ of $\mathrm{NaCl}$ and sea salts (Sigma), respectively. Catalase and oxidase activities were determined according to the protocols described by Smibert \& Krieg (1994), and gelatinase, amylase and degradation of Tweens 40 and 80 were examined as described by Hansen \& Sørheim (1991). In addition, nitrate reduction, indole production, arginine dihydrolase, urease, gelatinase and $\beta$-galactosidase activities, acid production from glucose and hydrolysis of aesculin were tested using an API 20NE kit (bioMérieux) according to the manufacturer's instructions except that cell suspensions were prepared using artificial seawater (ASW) $\left(1^{-1}\right.$ distilled water: $24 \mathrm{~g} \mathrm{NaCl}, 5.1 \mathrm{~g} \mathrm{MgCl}_{2}, 4 \mathrm{~g} \mathrm{Na}_{2} \mathrm{SO}_{4}, 1.1 \mathrm{~g} \mathrm{CaCl}_{2}$, $0.7 \mathrm{~g} \mathrm{KCl}, 0.2 \mathrm{~g} \mathrm{NaHCO}_{3}, 0.1 \mathrm{~g} \mathrm{KBr}, 0.027 \mathrm{~g} \mathrm{H}_{3} \mathrm{BO}_{3}$, $0.024 \mathrm{~g} \mathrm{SrCl}_{2}, 0.003 \mathrm{~g} \mathrm{NaF}$; Lyman \& Fleming, 1940) as a suspension medium. Other enzyme activities were also assayed by using the API ZYM kit (bioMérieux) with culture suspension in ASW. Carbon utilization was tested on a basal medium supplemented with yeast extract $\left(1^{-1}\right.$ distilled water: $23.6 \mathrm{~g} \mathrm{NaCl}, 0.64 \mathrm{~g} \quad \mathrm{KCl}, \quad 4.53 \mathrm{~g}$ $\mathrm{MgCl}_{2} \cdot 6 \mathrm{H}_{2} \mathrm{O}, 5.94 \mathrm{~g} \mathrm{MgSO}_{4} \cdot 7 \mathrm{H}_{2} \mathrm{O}, 1.3 \mathrm{~g} \mathrm{CaCl} \cdot 2 \mathrm{H}_{2} \mathrm{O}$, $0.2 \mathrm{~g} \mathrm{NaNO}_{3}, 0.2 \mathrm{~g} \mathrm{NH}_{4} \mathrm{Cl}, 0.05$ g yeast extract; Bruns et al., 2001) containing $0.4 \%$ of the carbon source. Incubation was prolonged for 2 weeks.

The fatty acid methyl esters in whole cells were analysed by GC according to the instructions of the Microbial Identification System (MIDI) at the Korean Culture Center of Microorganisms in Seoul, Korea. The DNA $\mathrm{G}+\mathrm{C}$ content was determined by HPLC analysis of deoxyribonucleosides as described by Mesbah et al. (1989) after DNA purification by the method of Marmur (1961).

The 16S rRNA gene sequence of strain CL-CB462 ${ }^{\mathrm{T}}$ showed $91.5 \%$ and $91.3 \%$ sequence similarities to Balneola vulgaris and Balneola alkaliphila, respectively, and formed a robust clade with the Balneola species in three phylogenetic trees that were constructed with different methods (Fig. 1 and Supplementary Figs S1 and S2, available in IJSEM Online). However, strain CL-CB462 ${ }^{\mathrm{T}}$ did not form a clade with $R$. marinus and $S$. ruber and the sequence similarities with these species were much lower, ranging from 79.8 to $81.4 \%$. The low $16 \mathrm{~S}$ rRNA gene sequence similarity between strain CL-CB462 ${ }^{\mathrm{T}}$ and $B$. vulgaris suggests that they could be recognized as representing different genera. Interestingly, the two extremophiles, $R$. marinus and $S$. ruber, and the three non-extremophiles, including strain CL-CB $462^{\mathrm{T}}$, formed two distinct clades, and were not clustered together in the phylogenetic trees (Fig. 1). The habitats and their physiology are also greatly different between the two groups (Table 1).

Cells of strain CL-CB462 ${ }^{\mathrm{T}}$ in exponential growth phase were long irregular rods of $0.2-0.3 \mu \mathrm{m}$ in width and 6.5$17.7 \mu \mathrm{m}$ in length (Fig. 2). Spore-like dark and bright coccoid cells were also observed in the culture (Fig. 2) and densely packed endospores were detected inside the cells by malachite green staining (data not shown). Cells were non- 


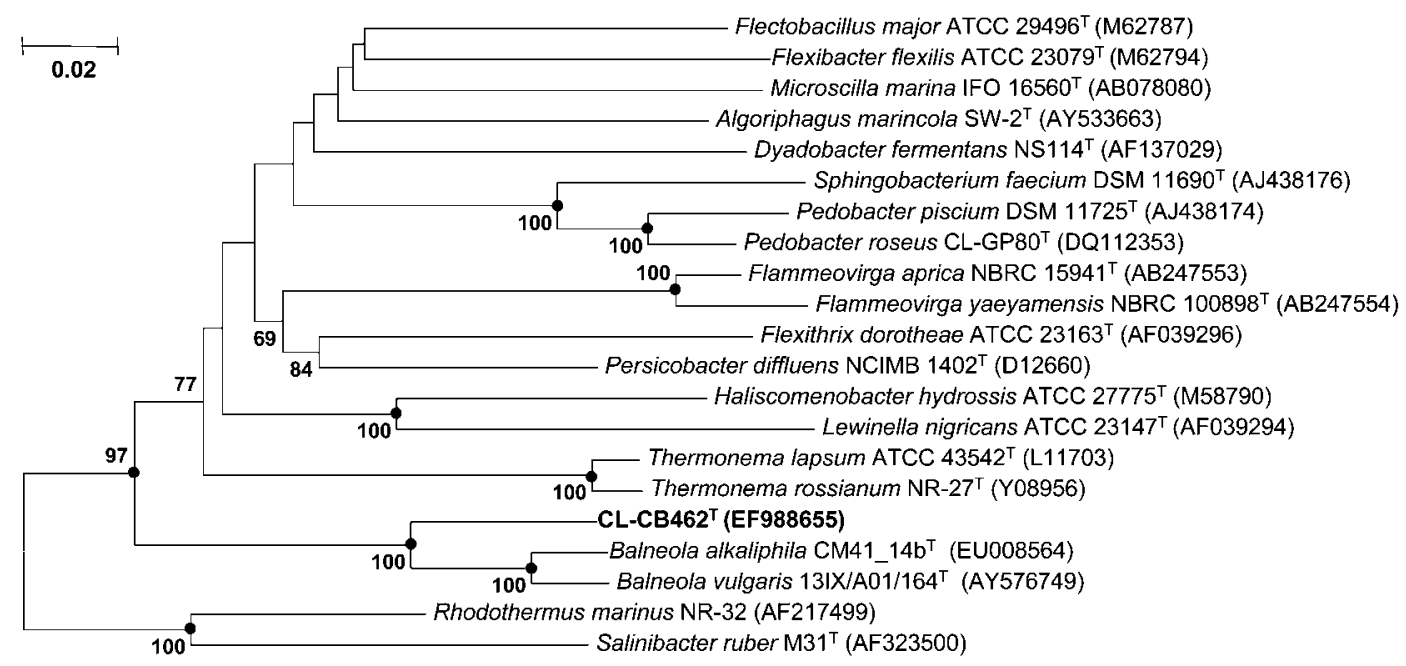

Fig. 1. Neighbour-joining tree showing the relationships between strain CL-CB462 ${ }^{\top}$ and other related species belonging to the phylum Bacteroidetes. Bootstrap values above $60 \%$, based on 1000 resamplings, are shown at the branching points. Solid circles indicate that the corresponding nodes are also recovered in maximum-parsimony and maximum-likelihood trees. Methylococcus capsulatus ACM $1292^{\top}$ (X72770) was used as the outgroup (not shown). Bar, 0.02 nucleotide substitutions per site.

motile and did not possess poly- $\beta$-hydroxybutyrate granules inside the cells. Colonies on MA were circular, entire, convex and orange. In anaerobic conditions, strain CL$\mathrm{CB} 462^{\mathrm{T}}$ grew very slowly and acid was produced from Dglucose. Flexirubin pigments were not detected.

Growth of strain CL-CB $462^{\mathrm{T}}$ was observed at temperatures of between 20 and $40{ }^{\circ} \mathrm{C}$, with optimum growth at $35^{\circ} \mathrm{C}$. Growth occurred over the range pH 6-10 (Table 1). Strain

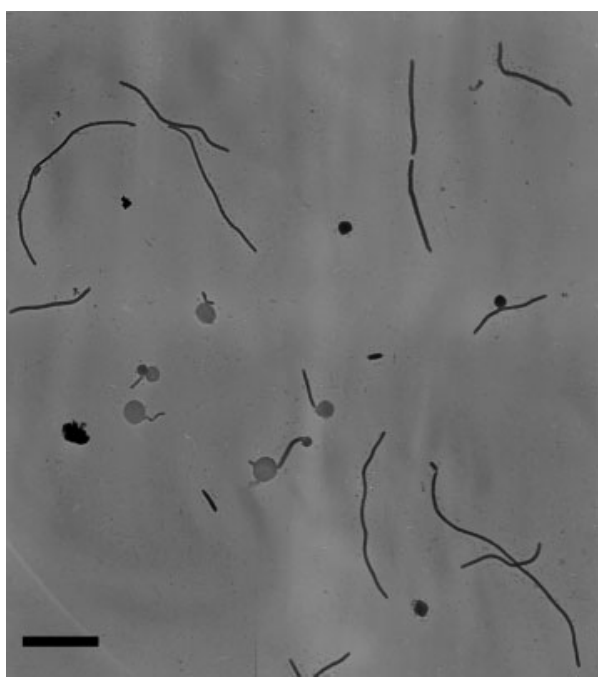

Fig. 2. Transmission electron micrograph of negatively stained cells of strain CL-CB $462^{\top}$. Bar, $5 \mu \mathrm{m}$.
CL-CB462 ${ }^{\mathrm{T}}$ could grow with sea salt concentrations of $1-$ $20 \%$, with optimum growth at 3-6\% (Table 1). The novel strain could not grow in media with $\mathrm{NaCl}$ as the sole salt. The strain could degrade starch, gelatin and Tweens 40 and 80. The results of other biochemical and physiological tests are given in Table 1 and the species description. The dominant fatty acids for strain CL-CB462 ${ }^{\mathrm{T}}$ were $15: 0$ iso (41.2\%), $17: 1 \omega 9 \mathrm{c}$ iso $(21.4 \%), 15: 0$ anteiso $(8.4 \%)$ and $15: 0$ iso $2-\mathrm{OH} / 16: 1 \omega 7 c(6.8 \%)$ (see Supplementary Table S1 in IJSEM Online).

Strain CL-CB462 ${ }^{\mathrm{T}}$ could be clearly differentiated from members of the genera Salinibacter and Rhodothermus by the differences in temperature and salinity ranges and the DNA G + C contents (Table 1). Further, the fatty acid profiles were conspicuously different (Supplementary Table S1). The phenotypic and physiological features of strain CL-CB462 ${ }^{\mathrm{T}}$ were also very different from those of the genus Balneola, which is the phylogenetically closest genus (Table 1). The novel strain forms long, irregular rods but the two Balneola species form relatively short rods. Other striking contrasts were also observed, namely spore formation, facultative anaerobic growth, sea salt requirement and growth at high salinity (up to $20 \%$ ). The fatty acid profile of strain CL-CB462 ${ }^{\mathrm{T}}$ was different from that of B. vulgaris, mainly in the proportions of $17: 1 \omega 9 \mathrm{c}$ iso, $15: 1 \omega 6 c, 15: 0$ anteiso and $17: 1 \omega 9 c$ anteiso (Supplementary Table S1). Enzyme activities, such as esterase, lipase, trypsin, naphthol-AS-BI-phosphohydrolase and $N$-acetyl- $\beta$-glucosaminidase, and carbon utilization patterns were also different between strain CL$\mathrm{CB} 462^{\mathrm{T}}$ and species of the genus Balneola (Table 1). Thus, 
Table 1. Selected characteristics that differentiate strain $C L-C B 462^{\top}$ from phylogenetically related strains

Strains: 1, CL-CB462 ${ }^{\mathrm{T}}$ (data from this study); 2, B. vulgaris 13IX/A01/164 ${ }^{\mathrm{T}}$ (Urios et al., 2006); 3, B. alkaliphila CM41_14b ${ }^{\mathrm{T}}$ (Urios et al., 2008); 4, S. ruber M31 ${ }^{\mathrm{T}}$ (Antón et al., 2002); 5, R. marinus (Alfredsson et al., 1988; Sako et al., 1996). +, Positive; -, negative; w, weakly positive; ND, no data available; $\mathrm{v}$, variable.

\begin{tabular}{|c|c|c|c|c|c|}
\hline Characteristic & 1 & 2 & 3 & 4 & 5 \\
\hline Isolation source & Seawater & Seawater & Seawater & $\begin{array}{c}\text { Crystallizer ponds } \\
\text { of salterns }\end{array}$ & $\begin{array}{c}\text { Submarine hot springs, } \\
\text { hydrothermal vent }\end{array}$ \\
\hline \multicolumn{6}{|l|}{ Cell characteristics } \\
\hline Shape & Long irregular rods & Rods & Rods & $\begin{array}{l}\text { Straight or slightly } \\
\text { curved rods }\end{array}$ & Rods \\
\hline Motility & - & + & - & + & - \\
\hline Spore-formation & + & - & - & - & - \\
\hline \multicolumn{6}{|l|}{ Temperature $\left({ }^{\circ} \mathrm{C}\right)$} \\
\hline Range & $20-40$ & $10-40$ & $15-37$ & $27-52$ & $50-85$ \\
\hline Optimum & 35 & 30 & 25 & $37-47$ & $65-80$ \\
\hline \multicolumn{6}{|l|}{ Salinity $\left(\mathrm{g} \mathrm{l}^{-1}\right)$} \\
\hline Range & $6-10$ & $5.0-10.0$ & $6-10$ & $6.0-8.5$ & $5.5-9.0$ \\
\hline Optimum & $7-8$ & 8 & $8-9$ & $6.5-8.0$ & 7 \\
\hline Anaerobic growth & w & - & - & - & - \\
\hline \multicolumn{6}{|l|}{ Enzyme activities } \\
\hline Cystine arylamidase & + & $\mathrm{w}$ & - & ND & ND \\
\hline Esterase (C4) & + & - & - & ND & ND \\
\hline Esterase lipase (C8) & + & $\mathrm{w}$ & - & ND & ND \\
\hline Lipase (C14) & $\mathrm{w}$ & - & - & ND & ND \\
\hline Oxidase & + & - & - & + & $\mathrm{v}$ \\
\hline Trypsin & - & + & + & $\mathrm{ND}$ & $\mathrm{ND}$ \\
\hline $\begin{array}{l}\text { Naphthol-AS-BI- } \\
\text { phosphohydrolase }\end{array}$ & + & - & - & $\mathrm{ND}$ & ND \\
\hline Galactose & - & - & - & - & + \\
\hline Glucose & + & + & $\mathrm{w}$ & - & + \\
\hline Lactose & - & $\mathrm{w}$ & - & - & + \\
\hline Mannitol & - & $\mathrm{w}$ & - & - & ND \\
\hline Sucrose & - & - & - & - & + \\
\hline DNA G $+C$ content $(\mathrm{mol} \%)$ & 42.7 & $41.8 \pm 1.1$ & $39 \pm 1$ & $66.3-67.7$ & $64.4-66.6$ \\
\hline
\end{tabular}

polyphasic evidence suggests that strain CL-CB462 ${ }^{\mathrm{T}}$ should be classified as a novel genus and species, for which the name Gracilimonas tropica gen. nov., sp. nov. is proposed.

\section{Description of Gracilimonas gen. nov.}

Gracilimonas [Gra.ci.li.mo' nas. L. adj. gracilis slim, slender, thin; L. fem. n. monas a unit, monad; N.L. fem. n.
Gracilimonas thin unit (bacterium), relating to its shape].

Cells are Gram-negative and irregular rods. Growth is heterotrophic. Aerobic and facultatively anaerobic. Positive for endospore staining. Catalase- and oxidase-positive. Absence of poly- $\beta$-hydroxybutyrate granules. Dominant fatty acids are $15: 0$ iso and $17: 1 \omega 9 \mathrm{c}$ iso. The type species is Gracilimonas tropica. 


\section{Description of Gracilimonas tropica sp. nov.}

Gracilimonas tropica [tro' pi.ca. L. fem. adj. tropica tropical, of or pertaining to the tropic(s), relating to its isolation from a tropical ocean].

Exhibits the following properties in addition to those given in the genus description. Cells are long and thin rods, approximately $0.2-0.3 \mu \mathrm{m}$ wide and $6.5-17.7 \mu \mathrm{m}$ long. Cells are non-motile. On MA, colonies are circular, entire, convex, opaque and orange. Does not produce flexirubin pigments. Grows within the temperature range of $20-40{ }^{\circ} \mathrm{C}$ (optimum $35{ }^{\circ} \mathrm{C}$ ), at $\mathrm{pH}$ 6-10 and at sea salt concentrations of $1-20 \%(w / v)$. No growth without sea salts in the medium. Hydrolyses starch, gelatin and Tweens 40 and 80 . According to API 20NE tests, positive for gelatinase activity but negative for nitrate reductase, arginine dihydrolase and urease activities, indole production, acid production from glucose and aesculin hydrolysis. Acid is produced from glucose in ZOF medium. According to API ZYM tests, alkaline phosphatase, esterase (C4), esterase lipase (C8), weak lipase (C14), leucine arylamidase, valine arylamidase, cystine arylamidase, $\alpha$-chymotrypsin, acid phosphatase, naphthol-AS-BI-phosphohydrolase and $N$-acetyl- $\beta$-glucosaminidase activities are present, whereas $\alpha$-galactosidase, $\beta$-galactosidase, $\beta$-glucuronidase, $\alpha$-glucosidase, $\beta$-glucosidase, $\alpha$-mannosidase and $\alpha$-fucosidase activities are absent. Growth occurs on fructose, glucose and aspartate but not on acetate, citrate, galactose, mannitol, inositol, lactose, succinate or sucrose.

The type strain, CL-CB462 ${ }^{\mathrm{T}}\left(=\mathrm{KCCM} 90063^{\mathrm{T}}=\mathrm{DSM}\right.$ $19535^{\mathrm{T}}$ ), was isolated from a Synechococcus culture established from surface water of the tropical Pacific Ocean. The DNA G $+\mathrm{C}$ content of the type strain is $42.7 \mathrm{~mol} \%$.

\section{Acknowledgements}

This work was supported in part by research programmes (PP00720) of KORDI and by the BK21 project of the Korean Government.

\section{References}

Alfredsson, G. A., Kristjánsson, J. K., Hjörleifsdottir, S. \& Stetter, K. O. (1988). Rhodothermus marinus gen. nov., sp. nov., a thermophilic, halophilic bacterium from submarine hot springs in Iceland. J Gen Microbiol 134, 299-306.

Altschul, S. F., Gish, W., Miller, W., Myers, E. W. \& Lipman, D. J. (1990). Basic local alignment search tool. J Mol Biol 215, 403-410.

Antón, J., Oren, A., Benlloch, S., Rodríguez-Valera, F., Amann, R. \& Rosselló-Mora, R. (2002). Salinibacter ruber gen. nov., sp. nov., a novel, extremely halophilic member of the Bacteria from saltern crystallizer ponds. Int J Syst Evol Microbiol 52, 485-491.

Bernardet, J.-F., Nakagawa, Y. \& Holmes, B. (2002). Proposed minimal standards for describing new taxa of the family Flavobacteriaceae and emended description of the family. Int J Syst Evol Microbiol 52, 1049-1070.

Bruns, A., Rohde, M. \& Berthe-Corti, L. (2001). Muricauda ruestringensis gen. nov., sp. nov., a facultatively anaerobic, appen- daged bacterium from German North Sea intertidal sediment. Int $J$ Syst Evol Microbiol 51, 1997-2006.

Englen, M. D. \& Kelley, L. C. (2000). A rapid DNA isolation procedure for the identification of Campylobacter jejuni by the polymerase chain reaction. Lett Appl Microbiol 31, 421-426.

Fitch, W. M. (1971). Toward defining the course of evolution: minimum change for a specific tree topology. Syst Zool 20, 406-416.

Garrity, G. M., Bell, J. A. \& Lilburn, T. G. (2004). Taxonomic outline of the prokaryotes, pp. 316-320. In Bergey's Manual of Systematic Bacteriology, 2nd edn, release 5.0. New York: Springer.

Guillard, R. R. L. \& Ryther, J. H. (1962). Studies of marine planktonic diatoms. I. Cyclotella nana Hustedt, and Detonula confervacea (Cleve) Gran. Can J Microbiol 8, 229-239.

Hansen, G. H. \& Sørheim, R. (1991). Improved method for phenotypical characterization of marine bacteria. J Microbiol Methods 13, 231-241.

Jukes, T. H. \& Cantor, C. R. (1969). Evolution of protein molecules. In Mammalian Protein Metabolism, vol. 3, pp. 21-132. Edited by H. N. Munro. New York: Academic Press.

Lane, D. J. (1991). 16S/23S rRNA sequencing. In Nucleic Acid Techniques in Bacterial Systematics, pp. 115-175. Edited by E. Stackebrandt \& M. Goodfellow. Chichester: Wiley.

Lemos, M. L., Toranzo, A. E. \& Barja, J. L. (1985). Modified medium for oxidation-fermentation test in the identification of marine bacteria. Appl Environ Microbiol 49, 1541-1543.

Ludwig, W., Strunk, O., Westram, R., Richter, L., Meier, H., Yadhukumar, Buchner, A., Lai, T., Steppi, S. \& other authors (2004). ARB: a software environment for sequence data. Nucleic Acids Res 32, 1363-1371.

Lyman, J. \& Fleming, R. H. (1940). Composition of sea water. J Mar Res 3, 134-146.

Marmur, J. (1961). A procedure for the isolation of deoxyribonucleic acid from microorganisms. J Mol Biol 3, 208-218.

Mesbah, M., Premachandran, U. \& Whitman, W. B. (1989). Precise measurement of the $\mathrm{G}+\mathrm{C}$ content of deoxyribonucleic acid by highperformance liquid chromatography. Int J Syst Bacteriol 39, 159-167.

Ostle, A. G. \& Holt, J. G. (1982). Nile blue A as fluorescent stain for poly- $\beta$-hydroxybutyrate. Appl Environ Microbiol 44, 238-241.

Posada, D. \& Crandall, K. A. (1998). MODELTEST: testing the model of DNA substitution. Bioinformatics 14, 817-818.

Pruesse, E., Quast, C., Knittel, K., Fuchs, B., Ludwig, W., Peplies, J. \& Glöckner, F. O. (2007). SILVA: a comprehensive online resource for quality checked and aligned ribosomal RNA sequence data compatible with ARB. Nucleic Acids Res 35, 7188-7196.

Saitou, N. \& Nei, M. (1987). The neighbor-joining method: a new method for reconstructing phylogenetic trees. Mol Biol Evol 4, 406425.

Sako, Y., Takai, K., Ishida, Y., Uchida, A. \& Katayama, Y. (1996). Rhodothermus obamensis sp. nov., a modern lineage of extremely thermophilic marine bacteria. Int J Syst Bacteriol 46, 1099-1104.

Smibert, R. M. \& Krieg, N. R. (1994). Phenotypic characterization. In Methods for General and Molecular Bacteriology, pp. 607-654. Edited by P. Gerhardt, R. G. E. Murray, W. A. Wood \& N. R. Krieg. Washington, DC: American Society for Microbiology.

Stoecker, K., Bendinger, B., Schöning, B., Nielsen, P. H., Nielsen, J. L., Baranyi, C., Toenshoff, E. R., Daims, H. \& Wagner, M. (2006). Cohn's Crenothrix is a filamentous methane oxidizer with an unusual methane monooxygenase. Proc Natl Acad Sci U S A 103, 2363-2367.

Swofford, D. L. (1998). PAUP: Phylogenetic analysis using parsimony (and other methods), version 4. Sunderland, MA: Sinauer Associates. 
Tamura, K., Dudley, J., Nei, M. \& Kumar, S. (2007). MEGA4: Molecular evolutionary genetics analysis (MEGA) software version 4.0. Mol Biol Evol 24, 1596-1599.

Urios, L., Agogué, H., Lesongeur, F., Stackebrandt, E. \& Lebaron, P. (2006). Balneola vulgaris gen. nov., sp. nov., a member of the phylum
Bacteroidetes from the north-western Mediterranean Sea. Int J Syst Evol Microbiol 56, 1883-1887.

Urios, L., Intertaglia, L., Lesongeur, F. \& Lebaron, P. (2008). Balneola alkaliphila sp. nov., a marine bacterium isolated from the Mediterranean Sea. Int J Syst Evol Microbiol 58, 1288-1291. 